\title{
Water mites (Hydrachnidia, Acari) in the lakes of the Masurian Landscape Park, Poland
}

\author{
Maria CICHOCKA \\ Department of Ecology and Environmental Protection, University of Warmia and Mazury, Pl. Łódzki 3, \\ 10-727Olsztyn,Poland; e-mail: mcich@uwm.edu.pl
}

\begin{abstract}
Mazurian lakes. Six faunal elements were distinguished: lacustrine, eurytopic typical of small water bodies, tyrphophilic, rheobiontic, rheophilic and astatic spring fauna. The species structure was dominated by the lacustrine element, and the numerical structure - by eurytopic species occurring in small water bodies. Six species indicatory of moderate lake eutrophy were recorded, i.e. Atractides ovalis, Limnesia polonica, Unionicola mionor, Piona stjoerdalensis, P. rotundoides, Forelia spatulifera and Atractides lacustris, indicating mesotrophy, was trapped in Lake Mokre only. The lakes examined are characterized by rather low faunal similarity. The highest degree of similarity was noted between two dystrophic lakes, Klimunt and Skarp, whereas Lake Majcz Wielki showed the greatest faunal distinctness.
\end{abstract}

Key words: lakes, water mites, synecological groups, indicators of mesotrophy and low eutrophy, faunal similarity

\section{INTRODUCTION}

The water mites of Polish lakes have been described by numerous authors, especially in the regions of Wielkopolska (Tutaj 1936, Biesiadka 1972a, 1972b, 1977, 1980, 2003; Zawal 1992), Łęczna-Włodawa Lakeland (Kowalik 1973, 1978, 1984) and Masurian Lakeland (Łazowska 1953, Pieczyński 1959, 1960, 1961, 1963, 1976; Cichocka \& Biesiadka 1994; Cichocka 1998, 2000, in press). The studies conducted by Pieczyński (l. c.) also contributed to a better understanding of the ecology of lacustrine water mites. Among his reports, particular attention should be paid to a review summarizing long-term research in this area (Pieczyński 1976). At the end of the $20^{\text {th }}$ century and at the beginning of the $21^{\text {st }}$ century. there appeared several publications dealing with water mites trapped in lakes with a different trophic status. The investigations were carried out in mesotrophic (Cichocka \& Biesiadka 1994, Cichocka 2003, in press), strongly eutrophicated (Cichocka 2000) and dystrophic lakes (Cichocka \& Biesiadka 1994, Cichocka 1998). Lake eutrophication results in faunal impoverishment. In the case of water mites this process is connected with the disappearance of species normally found in deeper zones, and increasing numbers of eurytopic species in the shallow littoral zone. The problems of lacustrine species extinction and protection have been already brought up by Biesiadka (1987), and Biesiadka \& Kowalik (1991). It follows that there is an urgent need to investigate and document the Hydrachnidia in the lakes exposed to a relatively low degree of anthropopressure, i.e. located in protected areas. The objects of special interest are mesotrophic lakes with their specific fauna of postglacial relicts. There are few such lakes in Poland, and only planned catchment management can prevent their degradation (Żmudziński 1990, Szlauer \& Szlauer 1997).

This paper presents the results of studies on the Hydrachnidia of lakes with a different trophic status, located in the Masurian Landscape Park. The studies focused on the species structure, synecological structure and vertical distribution of water mites, and faunal 
similarities between the lakes examined. An attempt was also made to evaluate the lakes on the basis of the occurrence of indicator species and values of synecological indices.

Previous reports by Pieczyński (1963), concerning the water mite fauna of 41 lakes located in the Krutynia River basin, provided information on 35 species described from 10 lakes of the Masurian Landscape Park.

\section{STUDY AREA}

Lakes are the main element of the hydrographic network of the Masurian Landscape Park. The majority of them are located within the Vistula River basin, only Lakes Wierzbowskie, Probarskie, Wagiel and Kuc, situated in the north-western part of the Park, belong to the Pregoła River Basin. There are 60 water bodies covering an area of over 1 ha in the Park, and 42 bigger ones, whose area exceeds 5 ha. They were formed by the Würm glaciation, which shaped the landscape in this region. The following types of lakes can be found there: deep ribbon lakes, surrounded by forests (Mokre, Mikołajskie, Bełdany), cave-in lakes (Kołowin, Kołowinek, Piersławek) and morainal lakes covering large areas, with diverse shorelines, not too deep, with bays and peninsulas (Śniardwy, Gardyńskie, Duś). The process of their aging is advanced, so most of them represent the eutrophic type. Mesotrophic lakes are few (Polakowski \& Strumiłło 1985), and especially valuable. The majority of them are flowthrough lakes. The lakes within the hydrographic network of the Masurian Landscape Park are connected by rivers, first of all Krutynia - which has its source in Lake Krutyńskie and flows into Lake Gardyńskie, Uklanka - connecting Lake Mojtyny to Lake Mokre, Blankowa Struga connecting Lake Wiskolisko to Lake Kaczerajno, and the streams of Pierwos - connecting the Krutynia River and lakes Kołowinek, Pierwos and Skok. There are also over 20 small, dystrophic forest lakes with acid water in the Krutynia River basin, occupying inland depressions, usually in sandy areas.

The studies were conducted on seven selected lakes (Fig. 1):

1. Lake Mokre (sampling sites 1-3) is located in the south-western part of the Masurian Landscape Park and covers an area of 814.8 ha. Its maximum and mean depth is $51 \mathrm{~m}$ and 12.7 $\mathrm{m}$, respectively. This is a ribbon lake, with a diverse and well-developed shoreline, $25,880 \mathrm{~m}$ in length. Its bed is sandy-gravelly. The phytolittoral zone is well-developed, composed mainly of Juncus sp., Carex sp., Schoenoplectus lacustris and Phragmites australis. Submerged vegetation is formed by Potamogeton perfoliatus, Myriophyllum sp. and Fontinalis antypyretica. The catchment is mostly afforested, only in the north the lake is surrounded by wet meadows, and in the west, in the central part by fields and meadows (Waluga \& Chmielewski 1998). The lake is used for recreation purposes, there are three tourist centers and campsites on its shore. According to Hilbricht-Ilkowska (1989) and expert opinions submitted by the State Environmental Inspectorate (Żyła-Pietkiewicz \& Imieliński) 1998, this lake can be classified as mesotrophic, but threatened by further eutrophication. Samples were taken on the western and eastern shores, in the vertical profile, from the shallowest littoral zone $(0.2 \mathrm{~m})$ to a depth of $20 \mathrm{~m}$. A total 25 samples were taken (10 with a dredge).

2. Lake Majcz Wielki (sampling site 4) is located in the north-western part of the Masurian Landscape Park, north of the nature reserve "Strzałowo", and covers an area of 162.5 ha. Its maximum and mean depth is $16.4 \mathrm{~m}$ and $6 \mathrm{~m}$, respectively. The lake has a well-developed shoreline, $8,200 \mathrm{~m}$ in length. The shores are partly overgrown with dense stands of Phragmites australis, Heleocharis palustris, Typha sp. and Juncus sp. Submerged vegetation is formed by Myriophyllum sp. and Fontinalis sp. The catchment is afforested in the south and east, with fields and meadows in the north and west (Waluga \& Chmielewski 1998). The lake is not used for recreation, but as a fishing center. It is a mesotrophic water body (Hilbricht-Ilkowska 1989, 
Żyła-Pietkiewicz \& Imieliński 1998). Samples were collected on the western shore, near a beach in the village Lipowo. Only four samples were taken, one of them with a dredge, at a depth of $2 \mathrm{~m}$.

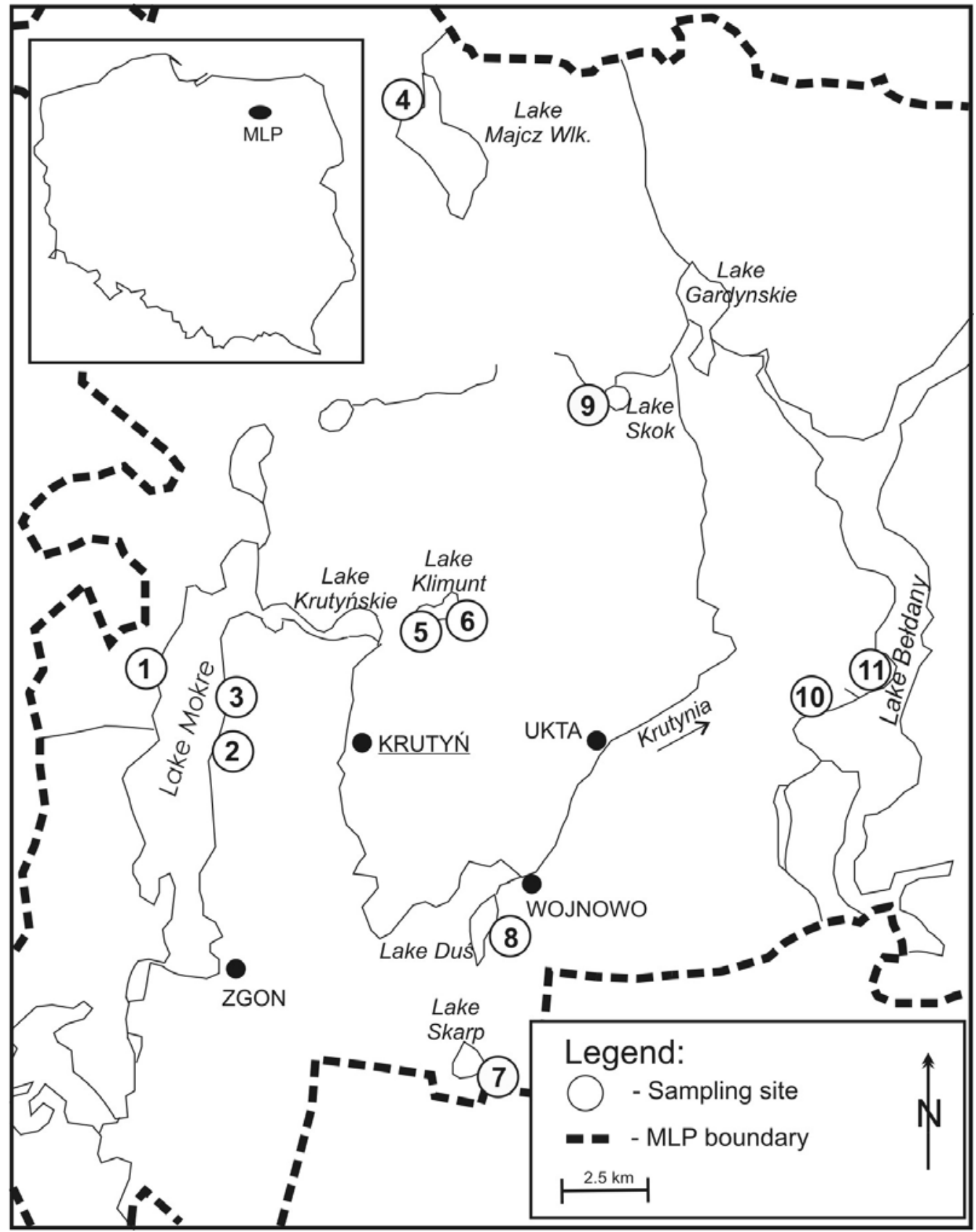

Fig. 1. Study area; MLP - Masurian Landscape Park. 
3. Lake Klimunt (sampling sites 5-6) is located in the western part of the Park, east of the nature reserve "Krutynia". This is a small lake, covering an area of 11.8 ha. Its maximum and mean depth is $5.5 \mathrm{~m}$ and $2.2 \mathrm{~m}$, respectively. The shoreline, $2,070 \mathrm{~m}$ in length, is relatively well-developed. The bottom is sandy, with a thick layer of organic deposit. The shores are overgrown with communities dominated by Phragmites australis, Acorus calamus, Equisetum limosum, Juncus sp. and Calla palustris, in some places also Glyceria fluitans, Comarum palustre, Menyanthes trifoliata and Lycopus europaeus. The catchment is afforested. According to Kruszelnicki \& Kruszelnicka (2000), this lake is mesotrophic, but HilbrichtIlkowska (1989) classified it as dystrophic. Samples were taken on the eastern and southeastern shores, to a depth of $1.5 \mathrm{~m}$ (one sample was taken with a dredge). A total of 15 samples were collected at these sites.

4. Lake Skarp (sampling site 7) is located in the south-western part of the Park. Its area is $23.4 \mathrm{ha}$, maximum and mean depth is $10.5 \mathrm{~m}$ and $5.7 \mathrm{~m}$ respectively. The shoreline is $2,000 \mathrm{~m}$ in length. The bed is sandy, in places it is silted up, with a layer of organic remains. The shores are overgrown with Carex sp. and Phragmites australis communities. Submerged plants are mainly Polygonum amphibium, Potamogeton natans and Myriophyllum sp. The catchment is afforested (Waluga \& Chmielewski 1998). This is a mesotrophic lake (Hilbricht-Ilkowska 1989). Samples were collected on the north-western shore only, to a depth of $1.5 \mathrm{~m}$ (one with a dredge). 11 samples were taken at this sampling point.

5. Lake Duś (sampling site 8) is located in the south-western part of the Masurian Landscape Park. It covers an area of 35.5 ha. Its maximum depth is $6 \mathrm{~m}$, mean depth is $2.8 \mathrm{~m}$. The shoreline is $3,200 \mathrm{~m}$ in length. The bottom is sandy and stony, overgrown with filamentous algae. The shores are overgrown with dense stands of Phragmites australis, Glyceria maxima, Typha sp. and Carex sp. Submerged vegetation is composed of Myriophyllum sp., Potamogeton sp. and Ceratophyllum sp. The shores are flat, surrounded by meadows, often wet or marshy. The lake is polymictic-eutrophic (Hilbricht-Ilkowska 1989). Samples were collected on the eastern shore, in the vicinity of a monastery, in the shallow littoral zone, to a depth of $0.7 \mathrm{~m}$. Only four samples were taken.

6. Lake Skok (sampling site 9) is located at the southern border of the nature reserve "Pierwos". This is a small lake, covering an area of 8.5 ha. Its bed is muddy, in places sandy. The shores are overgrown with Phragmites australis, in places with Sparganium simplex. Potamogeton perfoliatus with filamentous algae dominates among submerged plants. The lake is strongly eutrophicated (Hilbricht-Ilkowska 1989). Samples were taken on the south-eastern shore, in the village Bobrówko, in the shallow littoral zone, to a depth of $1 \mathrm{~m}$. Six samples were collected.

7. Lake Beldany (sampling sites 10-11) is the southern link of the complex of Great Masurian Lakes. Its area is 940.6 ha, maximum depth $-46 \mathrm{~m}$, mean depth $-10 \mathrm{~m}$. The shoreline is $33,300 \mathrm{~m}$ in length. The shores are covered with extensive tree complexes of the Pisz Primeval Forest. The rivers Krutynia and Wygrynia flow into this lake. Lake Bełdany is used for recreation purposes. There are over ten tourist centers, holiday cottages, campsites and harbors on its shores. There are point-source sewage discharges within the catchment (treated effluents from two tourist centers on the shores, and from leisure centers in Wierzba and Ruciane). The wastewater from fishing centers under management of the Polish Angling Association in Ruciane, and municipal sewage carried to the Wygrynia River from Ruciane, are also discharged to the lake. The shores are covered with trees, there is a wide belt of Phragmites australis in the phytolittoral zone, in places Schoenoplectus lacustris, Juncus sp., Typha angustifolia and Carex sp. communities. Nuphar luteum and Potamogeton perfoliatus are scattered in small patches on the water surface. The bed is sandy-stony, slightly silty or muddy. Water is rather turbid. This eutrophic lake was classified into category III (Platner \& 
Wróblewska 2000). Samples were collected on the western shore, near the village Kamień (sampling site 10) and in the Lodowa Bay (sampling site 11), in the shallowest littoral zone, to a depth of $0.6 \mathrm{~m}$. Only six samples were taken.

\section{MATERIAL AND METHODS}

Field investigations were carried out in the Masurian Landscape Park in the summer of 2000 and 2001. In the year 2000 the material was collected on July 17-20 and September 18-21, and in the year 2001 - on June 8 and 15, and July 24. Most samples were collected using a scoop, but some (in deeper zones) were taken with a dredge. A total of 71 samples were collected at 11 sampling sites, including 13 taken with a dredge. In all lakes samples were taken in the littoral zone, to a depth of $1.5-2 \mathrm{~m}$ in homogenous habitats, and in Lake Mokre to a depth of $20 \mathrm{~m}$.

Faunal similarity dendrograms were made on the basis of the Bray-Curtis formula in the BioDiversity program.

\section{RESULTS}

\section{General characteristics of Hydrachnidia in the lakes of the Masurian Landscape Park}

The material collected in the seven lakes examined in the study comprised 2,229 water mites, including 2,138 imagines and 91 deutonymphs, representing 56 species (Table 1). From 12 to 29 species were identified in particular lakes. This number is not too high, especially that as many as 73 species were reported from other lakes in the Masurian Lakeland (Cichocka \& Biesiadka 1994, Cichocka in press). The majority of species occurred in low numbers. The most numerous species (774 individuals) was Hydrodroma despiciens. This species is abundant in various types of stagnant waters in the Masurian Lakeland (Cichocka 1998). It was present in all lakes except Majcz Wielki. Another common species was Limnesia maculata (266 individuals), found in all lakes. Numerous and frequent species was also Brachypoda versicolor (110 individuals). It was trapped in all lakes except Lake Klimunt. The following species were relatively abundant: Limnesia undulata, Piona conglobata, Hygrobates longipalpis, Unionicola minor and Arrenurus albator. Six faunal elements were distinguished in the examined lakes, i.e.: lacustrine, eurytopic typical of small water bodies, tyrphophilic, rheobiontic, rheophilic and astatic spring fauna.

Table 1. Number of water mites (Hydrachnidia) in the lakes of the Masurian Landscape Park.

\begin{tabular}{|c|c|c|c|c|c|c|c|c|c|}
\hline & \multirow[b]{2}{*}{ Species } & \multicolumn{8}{|c|}{ Lakes } \\
\hline & & Mokre & $\begin{array}{l}\text { Majcz } \\
\text { Wielki }\end{array}$ & Klimunt & Skarp & Duś & Skok & Bełdany & Total \\
\hline 1 & 2 & 3 & 4 & 5 & 6 & 7 & 8 & 9 & 10 \\
\hline 1 & Limnochares aquatica (Linnaeus, 1758) & & & 45 & 21 & & & & 66 \\
\hline 2 & Eylais undulosa Koenike,1897 & & & 1 & & & & & 1 \\
\hline 3 & Hydrodroma despiciens (O. F. Müller, 1776) & 108 & & 352 & 249 & 16 & 14 & 35 & 774 \\
\hline 4 & Lebertia dubia Thor, 1889 & 2 & & & & & & & 2 \\
\hline 5 & Lebertia exuta Koenike, 1908 & 6 & & & & & & & 6 \\
\hline 6 & Lebertia porosa Thor, 1900 & & 5 & 2 & & & & & 7 \\
\hline 7 & Oxus longisetus (Berlese, 1885) & & & & 2 & & & & 2 \\
\hline 8 & Oxus ovalis (O. F. Müller, 1776) & 26 & & 2 & 2 & & 5 & 1 & 36 \\
\hline 9 & Limnesia connata Koenike, 1895 & & & 1 & 11 & & 2 & & 14 \\
\hline 10 & Limnesia fulgida C. L. Koch, 1836 & & & & 6 & 29 & 1 & 1 & 37 \\
\hline 11 & Limnesia koenikei Piersig, 1894 & & & & & & & 1 & 1 \\
\hline 12 & Limnesia maculata (O. F. Müller, 1776) & 23 & 6 & 63 & 21 & 27 & 69 & 57 & 266 \\
\hline
\end{tabular}




\begin{tabular}{|c|c|c|c|c|c|c|c|c|c|}
\hline 1 & 2 & 3 & 4 & 5 & 6 & 7 & 8 & 9 & 10 \\
\hline 13 & Limnesia polonica Schechtel, 1910 & & & 5 & 18 & 2 & & & 25 \\
\hline 14 & Limnesia undulata (O. F. Müller, 1776) & 6 & 9 & & 3 & 17 & 23 & 7 & 65 \\
\hline 15 & Hygrobates calliger Piersig, 1896 & 4 & & & & & & & 4 \\
\hline 16 & Hygrobates longipalpis (Hermann, 1804) & 15 & 1 & 3 & 7 & 1 & 5 & 18 & 50 \\
\hline 17 & Hygrobates trigonicus Koenike, 1895 & & & & 4 & & & & 4 \\
\hline 18 & Hygrobates $s p$. & 11 & & & 1 & & 1 & & 13 \\
\hline 19 & Atractides lacustris (Lundblad, 1925) & 2 & & & & & & & 2 \\
\hline 20 & Atractides ovalis Koenike, 1883 & 2 & 1 & & 7 & & & 2 & 12 \\
\hline 21 & Unionicola crassipes (O. F. Müller, 1776) & 4 & & 38 & & 3 & & & 45 \\
\hline 22 & Unionicola inusitata Koenike, 1914 & 1 & & & & & & & 1 \\
\hline 23 & Unionicola minor (Soar, 1900) & 8 & 1 & 7 & & 57 & & & 73 \\
\hline 24 & Neumania deltoides (Piersig, 1894) & 7 & & 2 & & 7 & & & 16 \\
\hline 25 & Neumania vernalis (O. F. Müller, 1776 ) & 5 & & 14 & 5 & 21 & & 2 & 47 \\
\hline 26 & Piona carnea (C. L. Koch, 1836) & & & & & & 1 & & 1 \\
\hline 27 & Piona coccinea (C. L. Koch, 1836) & 6 & & 1 & & & & 6 & 13 \\
\hline 28 & Piona conglobata (C. L. Koch, 1836) & & & 15 & 2 & 9 & 4 & 33 & 63 \\
\hline 29 & Piona discrepans (Koenike, 1895) & & & & & & & 1 & 1 \\
\hline 30 & Piona disparilis (Koenike, 1895) & & & 1 & & & & & 1 \\
\hline 31 & Piona dispersa Sokolow, 1926 & & & 1 & & & 2 & & 3 \\
\hline 32 & Piona longipalpis (Krendowskij, 1878) & & 1 & & 2 & 2 & 1 & 1 & 7 \\
\hline 33 & Piona neumani (Koenike, 1883) & & & 1 & 3 & & & & 4 \\
\hline 34 & Piona obturbans (Piersig, 1896) & 6 & & 5 & & 7 & 2 & & 20 \\
\hline 35 & Piona pusilla (Neuman, 1875) & 1 & & 6 & 2 & 21 & 6 & & 36 \\
\hline 36 & Piona rotundoides (Thor, 1897) & & & & & 3 & 2 & & 5 \\
\hline 37 & Piona stjoerdalensis (Thor, 1897) & 6 & 1 & & & & 6 & 13 & 26 \\
\hline 38 & Piona variabilis (C. L. Koch, 1842) & & & 5 & 4 & 5 & 8 & 10 & 32 \\
\hline 39 & Hydrochoreutes krameri Piersig, 1896 & & & & 1 & & & & 1 \\
\hline 40 & Tiphys ensifer (Koenike, 1895) & & & & 2 & & & & 2 \\
\hline 41 & Pionopsis lutescens (Hermann, 1804) & & & & 8 & & & 1 & 9 \\
\hline 42 & Forelia liliacea (O. F. Müller, 1776) & 1 & & 2 & 1 & 2 & 1 & & 7 \\
\hline 43 & Forelia spatulifera (Marucci, 1907) & 13 & 1 & & & & 1 & 3 & 18 \\
\hline 44 & Brachypoda versicolor (O. F. Müller, 1776) & 20 & 5 & & 3 & 8 & 60 & 14 & 110 \\
\hline 45 & Midea orbiculata (O. F. Müller, 1776) & 4 & & 1 & & 1 & 1 & & 7 \\
\hline 46 & Mideopsis orbicularis (O. F. Müller, 1776) & 20 & 3 & 15 & 6 & & & & 44 \\
\hline 47 & Arrenurus albator (O. F. Müller 1776) & 2 & 1 & 32 & 36 & & & & 71 \\
\hline 48 & Arrenurus bicuspidator Berlese, 1885 & 1 & & & 1 & 1 & 1 & & 4 \\
\hline 49 & Arrenurus claviger Koenike, 1885 & & & & 15 & & & & 15 \\
\hline 50 & Arrenurus crassicaudatus Kramer, 1875 & & & & & & 5 & 1 & 6 \\
\hline 51 & Arrenurus cuspidator ( O.F. Müller, 1776) & & & & & & 1 & & 1 \\
\hline 52 & Arrenurus globator (O.F. Müller, 1776) & 7 & & & 28 & 8 & 3 & & 46 \\
\hline 53 & Arrenurus latus Barrois et Moniez, 1878 & & & & & & 1 & & 1 \\
\hline 54 & Arrenurus neumani Piersig, 1895 & & & 1 & & 1 & & & 2 \\
\hline 55 & Arrenurus sinuator (O. F.Müller, 1776) & & & & & & 5 & 7 & 12 \\
\hline \multirow[t]{5}{*}{56} & Arrenurus tubulator (O.F. Müller, 1776) & & & & & 1 & & & 1 \\
\hline & Imagines total & 317 & 35 & 621 & 471 & 249 & 231 & 214 & 2138 \\
\hline & Hydrachnidia sp. dny & 19 & 5 & 32 & 7 & & & 28 & 91 \\
\hline & Imagines + dny & 336 & 40 & 653 & 478 & 249 & 231 & 242 & 2229 \\
\hline & Number of species & 28 & 12 & 26 & 29 & 23 & 27 & 20 & 56 \\
\hline
\end{tabular}


The lacustrine element (Fig. 2) dominated the species structure (28 species). The eurytopic species occurring in small water bodies showed large species diversity (19). The group of tyrphophilic water mites was represented by six species. Two rheophilic species were found, Hygrobates longipalpis and Lebertia dubia. One rheobiont (Hygrobates calliger), one species of astatic spring fauna (Tiphys ensifer) and one species associated with old-river beds (Limnesia koenikei) were also identified. As regards to the numerical structure (Fig. 2), eurytopic species typical of small water bodies accounted for as much as $69 \%$ of the material collected. The most common species of this group was Hydrodroma despiciens. The lacustrine element, characterized by the widest species diversity, made up $24 \%$ of the material. Apart from Brachypoda versicolor, the other species of this group occurred in relatively low numbers. Tyrphophils accounted for $3.8 \%$ of water mites. Limnochares aquatica was quite abundant, similarly as in running waters. Rheophils and rheobionts constituted only $2.4 \%$ and $0.2 \%$, respectively. Astatic spring fauna was represented by two individuals only, and Limnesia koenikei - by one.

Species

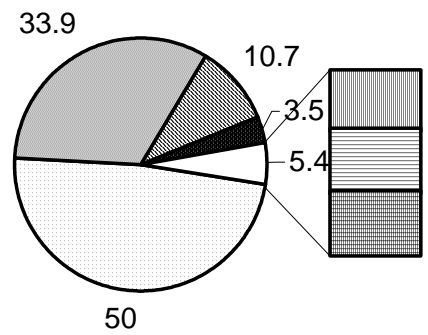

Individuals

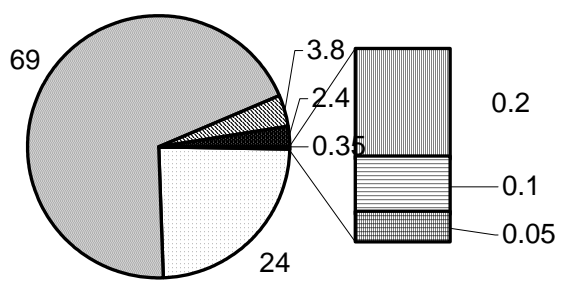

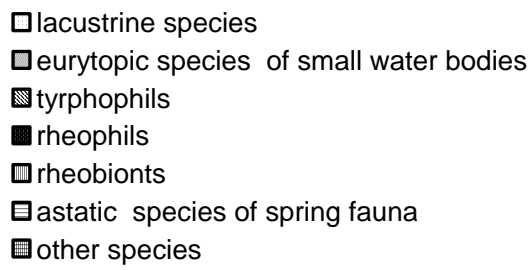

Fig. 2. Synecological characteristics of water mite fauna collected in the lakes of the Masurian Landscape Park.

Lake Mokre. Pieczyński carried out investigations on Lake Mokre in the 1963. This author collected samples in the shallow littoral zone only. He identified 13 water mite species, out of which six were also recorded during the present studies. 315 imagines belonging to 28 water mite species were trapped at sampling sites 1-3 in Lake Mokre (Table 2).

The group of eurytopic species typical of small water bodies was composed of nine species and made up 58\% of the material collected in this lake (Fig. 3). The most numerous species was Hydrodroma despiciens (34.2\% of the samples). It occurred in large numbers in the shallow littoral zone. It was much less common in deeper zones, and not found at all below 5 m. Other, less abundant, species were Oxus ovalis (8.2\%) and Limnesia maculata (7.3\%). Oxus ovalis was trapped in high numbers to a depth of $0.5 \mathrm{~m}$ in Carex $s p$. and Sparganium $s p$ 
communities. The lacustrine element of this lake was characterized by high species diversity (16), but lacustrine species were present in relatively low numbers (Fig. 3). The most abundant among them were: Brachypoda versicolor, Mideopsis orbicularis (both made up 6.3\% of the water mite population), Forelia spatulifera (4.1\%), Hygrobates sp. (3.5\%). The other 11 species accounted for $2.5-0.3 \%$ of the material. Lacustrine species preferred depths below $1 \mathrm{~m}$. Two rheophilic species were identified, i.e. Hygrobates longipalpis, relatively common $(4.76 \%)$ and Lebertia dubia (0.63\%). The latter was trapped at a depth of $3 \mathrm{~m}$. The rheobiont Hygrobates calliger (1.27\%) was found in the shallow littoral zone (at a depth of $0.4 \mathrm{~m}$ ) and at a depth of $3 \mathrm{~m}$ near the outflow to Lake Krutyńskie (sampling points 1 and 2).

Table 2. The occurrence of water mites (Hydrachnidia) in different depth's zones of the Lake Mokre; s. b. - sedge beds, S. s. - Sparganium simplex community; S. .l. - Schoenoplectus lacustris community; Ph. a. - Phragmites australis community; P. f. - Potamogeton filiformis community; M. sp. - Myriophyllum sp. community; P. p. Potamogeton perfoliatus community; F. a. - Fontinalis antypyretica; s. u. b. - sandy unvegetated bottom.

\begin{tabular}{|c|c|c|c|c|c|c|c|c|c|c|c|c|c|}
\hline \multirow{2}{*}{ No. } & \multirow[t]{2}{*}{ Depth } & \multicolumn{7}{|c|}{$0.5-1 \mathrm{~m}$} & \multirow{2}{*}{\begin{tabular}{|l|}
$1-2 \mathrm{~m}$ \\
$P . p$. \\
\end{tabular}} & \multicolumn{2}{|c|}{$2-4 \mathrm{~m}$} & \multirow{2}{*}{$\begin{array}{l}4-6 \mathrm{~m} \\
\text { s. u. b. }\end{array}$} & \multirow{2}{*}{ Total } \\
\hline & & s. b. & S. $s$. & S. $l$. & Ph.a. & $P . f$. & M. sp. & s. u. b. & & F. $a$. & s. u. b. & & \\
\hline 1 & Hydrodroma despiciens & & 10 & 4 & 1 & 2 & 17 & 58 & 5 & 7 & & 4 & 108 \\
\hline 2 & Lebertia dubia & & & & & & & & & 2 & & & 2 \\
\hline 4 & Lebertia exuta & & & & 2 & & & & & & 4 & & 6 \\
\hline 4 & Oxus ovalis & 9 & 12 & 1 & 2 & & & & & 1 & & 1 & 26 \\
\hline 5 & Limnesia maculata & & & & & 4 & 2 & 10 & 1 & 3 & & 3 & 23 \\
\hline 6 & Limnesia undulata & & & & & & & & & & 1 & 5 & 6 \\
\hline 7 & Hygrobates calliger & & 2 & & & & & & & 1 & 1 & & 4 \\
\hline 8 & Hygrobates longipalpis & 1 & & 4 & & 1 & 2 & 3 & 1 & 1 & 2 & & 15 \\
\hline 9 & Hygrobates sp. & & & & & & & 11 & & & & & 11 \\
\hline 10 & Atractides lacustris & & & & & & & & & & 2 & & 2 \\
\hline 11 & Atractides ovalis & 1 & 1 & & & & & & & & & & 2 \\
\hline 12 & Unionicola crassipes & & & 4 & & & & & & & & & 4 \\
\hline 13 & Unionicola inusitata & & & & & & & & & & & 1 & 1 \\
\hline 14 & Unionicola minor & & & & 3 & & & 2 & & & & 3 & 8 \\
\hline 15 & Neumania deltoides & & & & & & & & & 1 & 2 & 4 & 7 \\
\hline 16 & Neumania vernalis & & & 2 & & & & 1 & & 1 & & 1 & 5 \\
\hline 17 & Piona coccinea & & & & & 1 & & 5 & & & & & 6 \\
\hline 18 & Piona obturbans & & & & & & & 6 & & & & & 6 \\
\hline 19 & Piona pusilla & & & & & & & 1 & & & & & 1 \\
\hline 20 & Piona stjoerdalensis & & & & & 3 & 3 & & & & & & 6 \\
\hline 21 & Forelia liliacea & & & & & & & & & & 1 & & 1 \\
\hline 22 & Forelia spatulifera & & & & & & & & & 1 & & 12 & 13 \\
\hline 23 & Brachypoda versicolor & & 9 & & & & & 1 & 2 & 4 & & 4 & 20 \\
\hline 24 & Midea orbiculata & & 1 & & & & & & & 2 & 1 & & 4 \\
\hline 25 & Mideopsis orbicularis & & & & & & 3 & & 1 & 7 & & 9 & 20 \\
\hline 26 & Arrenurus albator & & & & & & & & & 2 & & & 2 \\
\hline 27 & Arrenurus bicuspidator & & & & & & & 1 & & & & & 1 \\
\hline 28 & Arrenurus globator & 1 & 6 & & & & & & & & & & 7 \\
\hline & Imagines total & 12 & 41 & 15 & 8 & 11 & 27 & 99 & 10 & 33 & 14 & 47 & 317 \\
\hline & Hydrachnidia sp. dny & 1 & - & - & 1 & - & 7 & - & - & 7 & 1 & 2 & 19 \\
\hline & Imagines + dny & 13 & 41 & 15 & 9 & 11 & 34 & 99 & 10 & 40 & 15 & 49 & 336 \\
\hline
\end{tabular}




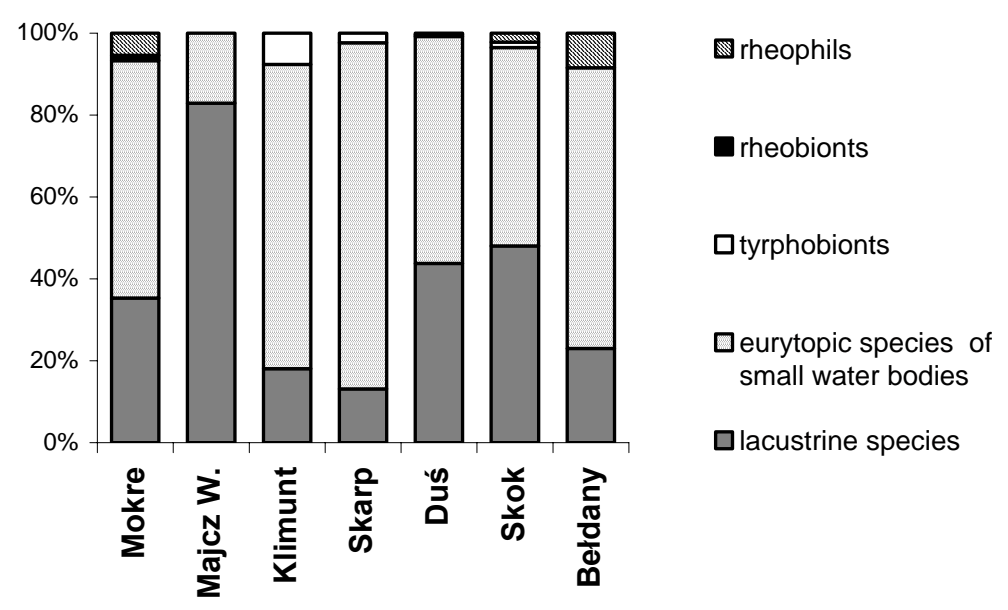

Fig. 3. Number of individuals representing synecological groups of water mite fauna in the lakes examined.

Samples were collected in Lake Mokre in the vertical profile, from the shallowest littoral zone $(0.2 \mathrm{~m})$ to a depth of $20 \mathrm{~m}$. Water mites were trapped to a depth of $6 \mathrm{~m}$ only (Fig. 4). In the shallowest littoral zone, to a depth of $0.5 \mathrm{~m}$, most species (10) were recorded among stands of Phragmites australis and Schoenoplectus lacustris, fewer on the unvegetated sandy bed (8) and in Sparganium simplex communities (7), and the fewest - in sedge belts (4). Most individuals were trapped on the unvegetated sandy bottom (80). In this habitat the dominant species was Hydrodroma despiciens (70\% of the population). Other abundant species were Limnesia maculata, Hygrobates sp. and Piona coccinea. Psammophilic species, associated with such habitats, were found sporadically only. The phytolittoral zone, dominated by Phragmites australis and Schoenoplectus lacustris, was characterized by larger species diversity, but fewer individuals were collected there (33). Most of them belonged to eurytopic species typical of small water bodies. 41 specimens were trapped in Sparganium simplex communities. Oxus ovalis, Hydrodroma despiciens and Brachypoda versicolor occurred in relatively large numbers. The rheobiont Hygrobates calliger was also trapped in this habitat. Only 12 water mites were found in the species-poor sedge belts. Species composition was generally poorer at a depth of 0.5 to $1 \mathrm{~m}$. Eight species were identified on the unvegetated sandy bed, similarly as in the shallowest zone, but the number of individuals was distinctly lower. Psammophilic species dominated there, including Hygrobates sp. and Piona obturbans. Five species were reported from Myriophyllum $s p$. communities. The dominant one was Hydrodroma despiciens. Species diversity was distinctly higher at a depth between 2 to $3 \mathrm{~m}$ (17). The majority of them (12) belonged to the lacustrine element. Forelia liliacea and Arrenurus albator occurred exclusively in this zone. Forelia spatulifera was trapped below 2 $\mathrm{m}$. The rheophil Lebertia dubia was also found there. Fewer species (9) were observed at a depth of $4 \mathrm{~m}$. The most numerous ones were Mideopsis orbicularis and Neumania deltoides. Nine species were identified at a depth of $5 \mathrm{~m}$, with a slightly higher number of individuals. The following species were collected most often: Forelia spatulifera, Mideopsis orbicularis and Limnesia undulata. The last one occurred from a depth of $2 \mathrm{~m}$. Particular attention should be paid to the rare species Atractides lacustris. Two specimens of Unionicola minor and Forelia spatulifera, were noted at a depth of $6 \mathrm{~m}$. 


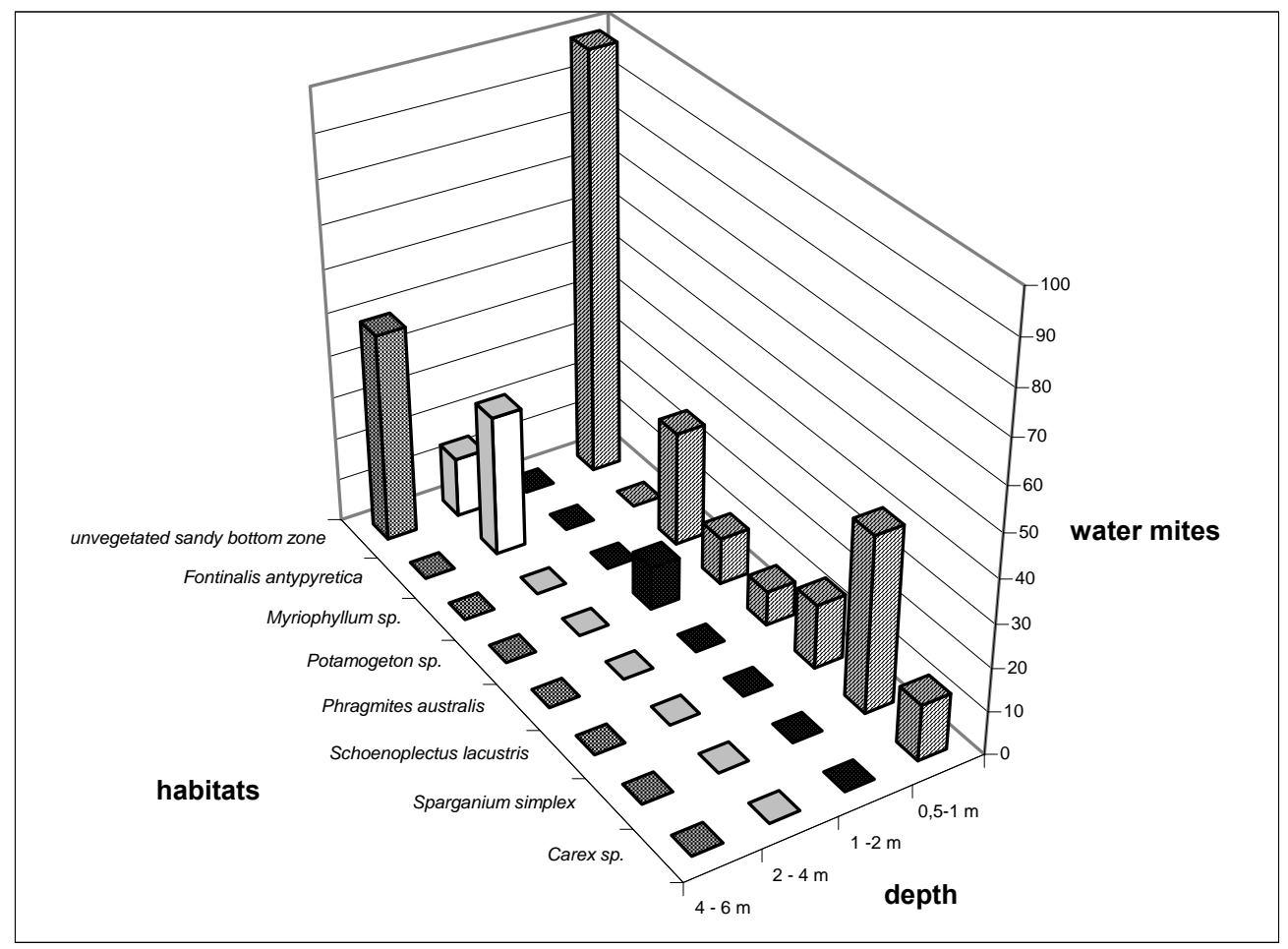

Fig. 4. Number of water mites individuals in different depth and habitat of the Lake Mokre.

Only one species indicatory of mesotrophy was identified in mesotrophic Lake Mokre, i.e. Atractides lacustris (Biesiadka \& Kowalik 1991; Cichocka 2003). Among 13 indicators of moderate eutrophy, only four were recorded in this lake, i.e. Atractides ovalis, Unionicola minor, Piona stjoerdalensis and Forelia spatulifera. Pieczyński (1963) noted Limnesia polonica in this group of indicators. According to Kowalik (1984), another indicator of mesotrophy is the proportion of psammophilic species, which in Lake Mokre was $19.2 \%$. The ratio between the lacustrine element and the eurytopic element typical of small water bodies was 0.66 (Cichocka 2000).

Lake Majcz Wielki. In Lake Majcz Wielki (sampling site 4) samples were collected at only one site, characterized by low habitat diversity. Only 12 species were identified (Table 1). All of them except Limnesia maculata belonged to the group of lacustrine water mites, accounting for $82.9 \%$ of the material (Fig. 3). The most numerous among them were Limnesia undulata (25.7\%), Brachypoda versicolor, Lebertia porosa (both 14.3\%) and Mideopsis orbicularis $(8.6 \%)$. The other species were represented by single individuals only. Higher faunal diversity and larger numbers of species were observed below $1 \mathrm{~m}$. Only five species were trapped in the shallow littoral zone, eight were collected at a depth of $2 \mathrm{~m}$. The same four species indicatory of moderate eutrophy as in Lake Mokre were also noted in Lake Majcz Wielki. They constituted $11.4 \%$ of the material collected at this site. The percentage of psammophilic species was much higher there $(28.6 \%)$. The ratio between the lacustrine element and the eurytopic element characteristic of small water bodies was 4.8. 
Lake Klimunt. 653 water mites (including 621 imagines and 32 deutonymphs), belonging to 26 species (Table 1), were collected in Lake Klimunt (sampling sites 5-6). Hydrodroma despiciens, representing the eurytopic element typical of small water bodies (Fig. 3), made up $56.6 \%$ of the material. It was present in all habitats to a depth of $0.8 \mathrm{~m}$. An abundant species in this group was Limnesia maculata (10.1\%), the other six eurytopic species accounted for $2.4-$ $0.2 \%$. 13 lacustrine species were identified, which constituted $18 \%$ of the water mite population collected in Lake Klimunt. The most abundant among them were Arrenurus albator and Mideopsis orbicularis. The rheophilic species Hygrobates longipalpis accounted for $0.5 \%$ only. Three tyrphophils were also found, Limnochares aquatica was most numerous (7.2\%) of them, the other two, i.e. Limnesia connata and Arrenurus neumani, were sporadically found (both $0.2 \%$ ). The highest numbers and species richness of water mites were observed in the shallowest littoral zone, to $0.5 \mathrm{~m}$. Both species abundance and number of individuals were gradually decreasing in deeper zones. Lacustrine Hydracarina species dominated there. At 1.5 $\mathrm{m}$ only two species were trapped, i.e. Mideopsis orbicularis (6 individuals) and Arrenurus albator (5). No species indicatory of mesotrophy were identified in the samples taken in Lake Klimunt. Two species indicating moderate eutrophy, Limnesia polonica and Unionicola minor, were found there. Psammophilic species made up $8.6 \%$ of the material. The ratio between lacustrine species and eurytopic species typical of small water bodies was as low as 0.25.

Lake Skarp. The samples taken in Lake Skarp contained 478 water mites (including 471 imagines), representing 29 species (Table 1). Eurytopic water mites typical of small water bodies (13 species) accounted for as much as $80 \%$ of the material (Fig. 3). Similarly as in Lake Klimunt, the most numerous species was Hydrodroma despiciens (52.9\%), whose numbers reduced considerably with depth. 175 individuals were trapped at $1 \mathrm{~m}, 45$ at $0.5 \mathrm{~m}$, seven at 0.8 , and one at $1 \mathrm{~m}$. The group of lacustrine water mites was diverse (12 species), but they occurs in low numbers. Arrenurus albator was most abundant (7.6\%), the other species made up $3.8-0.2 \%$ of the material. Three tyrphophilic species were also identified, i.e. Limnochares aquatica (4.46\%), Limnesia connata (2.34\%), Oxus longisetus $(0.42 \%)$, and one species representing astatic spring fauna, Tiphys ensifer $(0.42 \%)$. The highest species diversity and the largest number of individuals were recorded in the shallowest littoral zone. This zone showed also high habitat diversity. Six species were collected at $1 \mathrm{~m}$, and four lacustrine species below $1 \mathrm{~m}$, Hygrobates trigonicus (4 individuals), Limnesia undulata (1), Forelia liliacea (1), Brachypoda versicolor (1). No indicators of mesotrophy were found. The only species indicating moderate eutrophy identified in Lake Skarp, Atractides ovalis, made up 1.5\% of the water mite population collected there. Psammophilic species constituted $10.6 \%$ of the material. The ratio between the lacustrine element and the eurytopic element characteristic of small water bodies was as low as 0.15 .

Lake Duś. 249 individuals belonging to 23 water mite species (Table I) were identified in the material collected in the shallow littoral zone of Lake Duś (sampling point 8). Eurytopic water mites (9 species) made up $4.2 \%$ of the fauna (Fig. 3). Limnesia fulgida and L. maculata were most abundant (11.2\% and 10.4\% respectively). 12 lacustrine species were also found. The dominant species, both in this group and in the material collected, was Unionicola minor (21.9\%). Tyrphophils were represented by a single individual of Arrenurus neumani, and rheophils by Hygrobates longipalpis. Three species indicatory of moderate eutrophy were trapped: Limnesia polonica, Unionicola minor and Piona rotundoides. They constituted as much as $32.7 \%$ of water mites at this site. Psammophils accounted for $26.1 \%$ of the material. The ratio between lacustrine species and eurytopic species typical of small water bodies was 0.69 . 
Lake Skok. 232 water mites of 27 species (Table I) were collected in the shallowest littoral zone of Lake Skok (sampling site 9), including 13 eurytopic species, 13 lacustrine species and two tyrphophils. Eurytopic species typical for small water bodies accounted for as much as $50 \%$ of the material (Fig. 3). In contrast to the other lakes, the most numerous species in this group was Limnesia maculata (29.9\%). Hydrodroma despiciens constituted $6.1 \%$ of the material only. The percentage of the other 11 species varied from 3.5 to $0.4 \%$. The dominant lacustrine species was Brachypoda versicolor (26\%). Limnesia undulata also occurred in relatively high abundance (9.9\%). The remaining species accounted for $2.6-0.4 \%$ of water mites collected at this site. Two tyrphophilic species, Limnesia connata and Piona carnea, constituted $0.9 \%$ and $0.4 \%$ respectively. Piona stjoerdalensis and Piona rotundoides, indicators of moderate eutrophy, accounted for $3.5 \%$ of the material. Psammophilic species made up $26.4 \%$ of the material. The ratio between lacustrine species and eurytopic species occurring in small water bodies was 0.99 .

Lake Beldany. 242 water mites (including 214 imagines and 28 deutonymphs), belonging to 20 species (Table I), were collected in the shallow littoral zone of Lake Bełdany (sampling sites 10-11). Ten of them represented the eurytopic element occurring in small water bodies, nine - the lacustrine element, and one - the rheophilic element. A distinct domination of eurytopic species was observed. They constituted $68.2 \%$ of the water mites trapped in this lake (Fig. 3). The most abundant species were Limnesia maculata (26.6\%), Hydrodroma despiciens (16.4\%) and Piona conglobata (15.4\%). The other seven species of this group were present in low numbers $(4.7-0.5 \%)$. Lacustrine species made up $22.9 \%$ of the material. This group was dominated by Brachypoda versicolor (6.5\%) and Piona stjoerdalensis $(6.1 \%)$. The rheophil Hygrobates longipalpis accounted for $8.4 \%$. Water mites were found first of all in the phytolittoral zone, in stands of Schoenoplectus lacustris and Acorus calamus. 18 species were identified there, i.e. half of the water mite fauna collected in Lake Bełdany. Eight species were recorded in Potamogeton perfoliatus communities, and five in Nuphar luteum communities. Only two species were found on the unvegetated sandy-stony bed. Three species indicating moderate eutrophy, Atractides ovalis, Piona stjoerdalensis and Forelia spatulifera, made up $8.4 \%$ of the material. Psammophils constituted $6.5 \%$. The ratio between the lacustrine element and the eurytopic element typical of small water bodies was 0.33 .

\section{Comparative analysis of water mites in the lakes of the Masurian Landscape Park}

The lakes of the Masurian Landscape Park do not show high species diversity of the water mite fauna (12 to 29 species). Both the number of individuals and species richness decrease with depth. The lakes examined in the study were generally characterized by a low degree of faunal similarity (Fig. 5). It was the highest (60\%) between Lake Klimunt and Lake Skarp. These are inland and forest lakes, occasionally surrounded by Sphagnum sp., displaying a tendency towards dystrophication. The lacustrine element was species-poor in these lakes. Tyrphophils were also found there. Quite a high degree of faunal similarity was also noted between these two lakes and the eutrophic Lake Bełdany, which was also characterized by a high proportion of eurytopic species typical of small water bodies $(72 \%$, compared with about $80 \%$ in lakes Klimunt and Skarp) and a small proportion of the lacustrine element and psammophils. The degree of faunal similarity between the above mentioned lakes and Lake Mokre was $42 \%$. However, many more lacustrine species were identified there, although eurytopic species dominated in terms of numbers, and Hydrodroma despiciens was the most abundant of them. The percentage of psammophils was much higher there. Lake Mokre shows also some similarity to Lake Duś. In the latter the percentage of lacustrine and psammophilic species were even somewhat higher than in the former. The lacustrine species Unionicola 
minor was present in the highest abundance in Lake Duś. This emphasizes the special natural values of this lake, and its better ecological condition, in comparison with other eutrophic lakes, like Bełdany or Skok. In these lakes the dominant species was Limnesia maculata, representing the eurytopic element. Brachypoda versicolor was also quite abundant, especially in Lake Bełdany.

Bray-Curtis Cluster Analysis (Group Awerage Link)

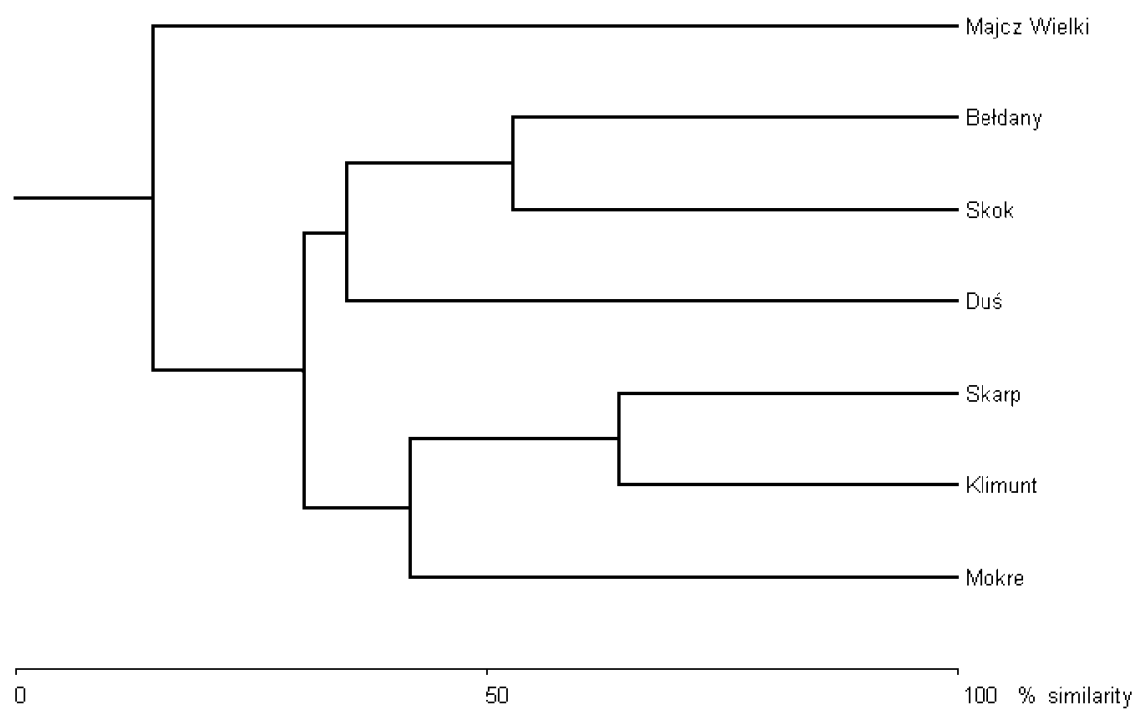

Fig. 5. Faunal similarity of water mites in the lakes examined.

Lake Majcz Wielki, compared with the other lakes examined, was characterized by the highest degree of faunal distinctness, which manifested itself, among other, by distinct domination of the lacustrine element. The proportion of species indicating moderate eutrophy was also relatively high in this lake (11.4\%). The percentage of the lacustrine element was very high there. The ratio between lacustrine species and eurytopic species occurring in small water bodies was almost 5 to 1 , whereas in the other lakes it varied from 0.15 to 0.99 . Psammophils accounted for $28.6 \%$ of the water mite fauna. In this respect Lake Majcz Wielki resembles lakes Mokre and Duś.

\section{DISCUSSION}

The lakes of the Masurian Landscape Park examined in this study are characterized by low species diversity (12 to 29 species). A similar diversity was reported by Pieczyński (1963), who recorded 8 to 28 species in ten lakes of the Masurian Landscape Park. The list of species compiled by this author included 35 species, of which only four were not found in the present investigations. With the exception of Frontipoda musculus, these species are non-specific to lakes. A total of 60 water mite species were identified in the lakes of the Masurian Landscape Park.

In comparison with other Polish lakes, both mesotrophic and eutrophic, the lakes of the Masurian Landscape Park are generally characterized by a low number of water mite species. However, in some lakes of the Łęczna-Włodawa Lakeland (Kowalik 1978) the number of 
species was also small (Zagłębocze - 21, Rogórzno - 26), similarly as in Lake Długie in Olsztyn - 28 (Cichocka 2000). Many more species were described from the following lakes: Tuczno - 96 (Biesiadka 2003), Tyrsko - 72 (Cichocka \& Biesiadka 1994), Zbęchy - 68 (Biesiadka 1980), Bialskie - 66 (Kowalik 1978), Babięty Wielkie - 63 (Cichocka in press), Piaseczno - 60 (Kowalik 1978), Skanda - 58 (Cichocka 2000), Kierskie - 49 (Biesiadka 1972b), Kraksy - 45 (Cichocka 2000), Łakie - 40 (Biesiadka \& Cichocka 1997). In all these lakes the number of individuals and species diversity were lower in deeper zones. In Lake Mokre samples were taken to a depth of $20 \mathrm{~m}$, but water mites were trapped to $6 \mathrm{~m}$ only. In Lake Babięty Wielkie water mites were found at $10 \mathrm{~m}$, and ten species were recorded between 5 and $7 \mathrm{~m}$ in depth (Cichocka in press). In Lake Tyrsko the population size of water mites was significantly lower below $10 \mathrm{~m}$, but species diversity was still quite large (16).

Eurytopic species typical of small water bodies dominated in the lakes of the Masurian Landscape Park (except Lake Majcz Wielki). These were Hydrodroma despiciens (lakes Mokre, Klimunt and Skarp) and Limnesia maculata (lakes Skok and Bełdany). These two species were also most numerous and trapped most frequently in 41 lakes located within the Krutynia River basin and in the neighborhood of Mikołajki (Pieczyński 1963). Other dominant species were Piona conglobata and two lacustrine species, Brachypoda versicolor and Unionicola crassipes. They were less abundant in the lakes examined in this study. A decrease in their numbers, especially of lacustrine species, compared with the data obtained in the 1960 (Pieczyński 1963), may indicate their gradual vanishing from the Masurian Lakeland, caused by increasing lake eutrophication. Relatively high abundance of the lacustrine element in the domination structure of the water mite fauna was noted in the lakes of the Łęczna-Włodawa Lakeland (Kowalik 1978), where eurytopic species as Piona coccinea, Hydrodroma despiciens, Limnesia maculata, P. pusilla, P. conglobata were accompanied by lacustrine water mites, Piona paucipora, Limnesia undulata, Hydrochoreutes krameri. The structure of the water mite fauna was completely different in eutrophic lakes Kierskie and Zbęchy (Biesiadka 1972a, 1972b, 1980), where faunal impoverishment resulted in the domination of lacustrine species. The fluvio-lacustrine species Hygrobates longipalpis dominated in Lake Kierskie. Lacustrine species, such as Unionicola intermedia, Hygrobates trigonicus, Limnesia undulata and Brachypoda versicolor, were also present in large numbers. The lacustrine element (Brachypoda versicolor, Hygrobates trigonicus and Mideopsis orbicularis) dominated also in Lake Zbęchy. In the Masurian Lakeland lacustrine species occurred in high abundance only in lakes characterized by low trophy. In the mesotrophic Lake Babięty Wielkie (Cichocka in press) the water mite fauna was dominated by the lacustrine species Limnesia undulata and Brachypoda versicolor. A similar situation was observed in Lake Tyrsko (Cichocka \& Biesiadka 1994), where Brachypoda versicolor was trapped most frequently. Also Lake Majcz Wielki was characterized by a similar domination structure. A few samples only were taken in this lake, which makes it difficult to evaluate its ecological condition, but the distinct domination of the lacustrine element indicates its high faunal values. The faunal distinctness of this lake was also confirmed by the fact that Hydrodroma despiciens was not collected there, although it was quite common in the littoral zones of the other lakes. The proportion of psammophils was also the highest in Lake Majcz Wielki, in comparison with the other lakes examined, but lower than in Lake Tyrsko and Lake Babięty Wielkie. In the other lakes of the Masurian Landscape Park this index was not high, which suggests higher trophy than in mesotrophic lakes like Tyrsko or Babięty Wielkie. However, it should be stressed that the percentage of psammophils was high in the littoral zones of some strongly eutrophicated lakes (Cichocka 2000). This stands in contradiction to the findings of Kowalik (1984), who claims that the relative number of psammophilic species is a good indicator of the trophic status of lakes. 
With the exception of Lake Mokre, species indicatory of mesotrophy were not identified in the lakes of the Masurian Landscape Park (Biesiadka \& Kowalik 1991). Atractides lacustris, reported previously from a few Polish lakes only, was found in Lake Mokre (Cichocka 2003). More relict species were recorded in other mesotrophic lakes in Poland. Postglacial relict fauna in the sense used by Biesiadka (1987) was most abundant in the following lakes: Tuczno eight species (Biesiadka 2003), Tyrsko - four species (Cichocka \& Biesiadka 1994), Łąkie and Babięty Wielkie - two species (Biesiadka \& Cichocka 1997, Cichocka in press), lakes of the Łęczna-Włodawa Lakeland - three species (Kowalik 1978). Indicators of mesotrophy were found even in eutrophic lakes of the Olsztyn Lakeland (Cichocka 2000), but in the majority of lakes of the Masurian Landscape Park samples were taken in the shallow littoral only, and these species are usually found at a depth of about $4 \mathrm{~m}$. Indicators of moderate eutrophy were noted in all lakes (Biesiadka \& Kowalik 1991). The value of this index was rather high in Lake Duś, Lake Majcz Wielki and Lake Mokre, compared with other Polish lakes. Species indicatory of moderate eutrophy were also reported from strongly eutrophicated lakes, but their percentages were low (Cichocka 2000). The conclusion is that the lakes of the Masurian Landscape Park are not extremely eutrophicated, because species known for highly specific ecological requirements were still present in relatively large numbers. With the exception of Lake Majcz Wielki, all of the lakes examined are eutrophic and should be protected against further degradation. In Lake Mokre relict water mites were accompanied by relict gammarids Pallasiola quadrispinosa, which indicates its good condition. Among all eutrophic lakes in the Park this one seems to be characterized by the lowest trophy.

\section{REFERENCES}

BIESIADKA E. 1972a. Wodopójki (Hydracarina) Wielkopolskiego Parku Narodowego. Prace Monograficzne nad Przyrodą Wielkopolskiego Parku Narodowego, Poznań, 5: 96-198.

BIESIADKA E. 1972b. Zmiany w faunie wodopójek (Hydracarina) jeziora Kierskiego. Pol. Pismo Entomol., Wrocław, 42: 263-271.

BIESIADKA E. 1977. Hydracarina. In: WróBLEWSKi A. (ed.), Bottom fauna of the heated Konin lakes. Monografie Fauny Polski, Kraków, 7: 281-350.

BIESIADKA E. 1980. Water mites (Hydracarina) of the eutrophic lake Zbęchy (Leszno voiv.). Pol. Ecol. Stud., Warszawa, 6: 246-262.

BIESIADKA E. 1987. Ginące gatunki wodopójek Hydracarina fauny jezior Polski i problem ich ochrony. Chrońmy Przyrodę Ojczystą, Kraków, 43: 16-21.

BIESIADKA E. 2003. Wodopójki Hydrachnidia jeziora Tuczno koło Międzychodu. Przegląd Przyrodniczy, Świebodzin, 14: 71-84.

BIESIADKA E. \& CichOCKA M. 1997. Hydracarina fauna in Lobelia-type lakes near Bytów. Fragm. Faun., Warszawa, 40: 81-93.

BIESIADKA E. \& KOWALIK W. 1991. Water mites (Hydracarina) as indicators of trophy and pollution in lakes. In: DusbabeK F. \& BuKVA V. (eds), Modern Acarology 1, pp.475-481 Academia, Prague and SPB Academic publishing, The Hague, 688 pp.

CicHOCKA M. 1998. Wodopójki (Hydracarina) torfowisk Pojezierza Mazurskiego. Studium faunistyczno-ekologiczne. Wyższa Szkoła Pedagogiczna, Olsztyn, 128 pp.

CichоскA M. 2000. Water mites (Hydracarina)of strongly eutrophic lakes in the Olsztyn Lake District. In: Ignatowicz S. (ed.), Akarologia polska u progu XXI wieku. Materiały z XXVI Sympozjum Akarologicznego, pp. 70-78. Wydawnictwo SGGW, Warszawa, 389 pp.

CichockA M. 2003. Nowe stanowiska Atractides lacustris (Lundblad, 1925) (Hydrachnellae, Actinedida) w jeziorach mezotroficznych na Pojezierzu Mazurskim. In: PrZYSTALSKI A. \& WILCZYŃSKA B. (eds), Zoologia na progu XXI wieku, pp. 102-103. Polskie Zrzeszenie Inżynierów i Techników Sanitarnych, Toruń, 277 pp.

CichocKA M. (in press). Water mites (Hydracarina) of the mesotrophic lake Babięty Wielkie (Mragowo Lakeland). Polish Journal of Natural Sciences, Wydawnictwo Uniwersytetu Warmińsko-Mazurskiego, Olsztyn.

CichOCKA M. \& BIESIADKA E. 1994. Wodopójki (Hydracarina) jezior mazurskich z Isoetes lacustris. In: KRASKA M. (ed.), Jeziora lobeliowe. Charakterystyka, funkcjonowanie i ochrona. Idee Ekologiczne 7, ser. Szkice, Poznań, 5: 75-83.

Hilbricht-ILKOwSKa A. (ed.) 1989. Jeziora Mazurskiego Parku Krajobrazowego. Stan eutrofizacji, kierunki ochrony. Zeszyty Naukowe Seria „Człowiek i środowisko”, Wydawnictwo PAN, Wrocław, 133 pp. 
KowALIK W. 1973. Wodopójki (Hydracarina) jezior sosnowickich na Pojezierzu Łęczyńsko-Włodawskim. Ann. UMCS Ser. C, Lublin, 28: 331-335.

KowALIK W. 1978. Występowanie wodopójek (Hydracarina) w jeziorach o różnej trofii na Pojezierzu ŁęczyńskoWłodawskim. Ann. UMCS Ser.C, Lublin, 33: 443-468.

KowALIK W. 1984. Studia faunistyczno-ekologiczne nad wodopójkami (Hydracarina) południowo-wschodniej Polski. Rozprawy Naukowe 83, Akademia Rolnicza, Lublin, 67 pp.

KruszelniCKi J. \& KRUSZELniCKA A. 2000. Mazurski Park Krajobrazowy. Przewodnik ilustrowany. Wydawnictwo KENGRAF, Kętrzyn, 64 pp.

ŁAZOWSKA M. 1953. Zespoły wodopójek górnego litoralu kilku jezior mazurskich. Ekol. Pol., Warszawa, 1: 67-81.

PIECZYŃSKI E. 1959.Wodopójki (Hydracarina) niektórych środowisk litoralnych jeziora Tajty oraz innych jezior mazurskich.. Ekol. Pol. Ser. A, Warszawa, 7: 145-168.

PIECZYŃSKi E. 1960. Kształtowanie się zgrupowań wodopójek (Hydracarina) w jeziorze Wilkus. Ekol. Pol. A, Warszawa, 8: 169-198.

PIECZYŃSKI E. 1961. Number, sex ratio, and fecundity of several species of water mites (Hydracarina) of Mikołajskie lake. Ekol. Pol. Ser. A, Warszawa, 9: 219-228.

PIECZYŃSKI E. 1963. Some regularites in the occurrence of water mites (Hydracarina) in the littoral of 41 lakes in the river Krutynia basin and the Mikołajki district. Ecol. Pol. Ser. A., Warszawa, 11: 141-157.

PIECZYŃSKI E. 1976. Ecology of water mites (Hydracarina) in lakes. Pol. Ekol. Stud., Warszawa, 2: 5-54.

PlatNer M. \& WRÓBleWSKA H. 2000. Monitoring jezior. In: RóżAŃSKi S. (ed.), Raport o stanie środowiska na obszarze województwa warmińsko-mazurskiego w latach 1997-1998, pp. 95-141. Biblioteka Monitoringu Środowiska, Olsztyn, 261 pp.

Polakowski B. \& StRumiŁŁo A. 1985. Mazurski Park Krajobrazowy. Ludowa Spółdzielnia Wydawnicza, Warszawa, $352 \mathrm{pp}$.

SzLAUER B. \& SzLAUER L. 1997. Wniosek o objęcie ochroną ginących gatunków skorupiaków, zasiedlających jeziora mezotroficzne. Przegląd Zoologiczny, Wrocław, 41: 145-147.

TutAJ J. 1936. Wodopójki (Hydracarina) najbliższych okolic Poznania ze szczególnym uwzględnieniem Jeziora Kierskiego. Prace Komisji Matematyczno-Przyrodniczej Poznańskiego Towarzystwa Przyjaciół Nauk, Poznań, 8: $1-74$.

Waluga J. \& ChMielewski H. 1998. Jeziora Pojezierza Mrągowskiego. Seria Przewodniki Wędkarskie 4. Wydawnictwo. Instytutu Rybactwa Śródlądowego, Olsztyn, 219 pp.

ZAWAL A. 1992. Water mites (Hydracarina) of three small lakes in the neighbourhood of Poznań. Acta Hydrobiol., Kraków, 34: 157-174.

ŻMUDZIŃSKI L. 1990. Past and recent occurrence of Malacostraca glacial relicts in Polish lakes. Ann. Zool. Fenn., Helsinki, 27: 227-230.

ŻYŁA-PIETKIEWICZ G. \& IMIELIŃSKI S. 1998. Stan czystości wód powierzchniowych stojących. In:. ŻyŁAPietKiewicz G. \& IMIELiŃSKi S. (eds), Stan czystości wód powierzchniowych obszaru Zielonych Płuc Polski, pp. 191-343. Biblioteka Monitoringu Środowiska. Państwowa Inspekcja Ochrony Środowiska, Białystok, 425 pp.

\section{STRESZCZENIE}

\section{[Wodopójki (Hydrachnidia, Acari) jezior Mazurskiego Parku Krajobrazowego]}

Badania nad wodopójkami jezior Mazurskiego Parku Krajobrazowego prowadzono w latach 2000 i 2001. Próby pobierano w 7 jeziorach na 11 stanowiskach. Łącznie pobrano 71 prób. Zebrany materiał obejmuje 2229 osobników, w tym 91 deutonimf. W badanych jeziorach stwierdzono występowanie 56 gatunków wodopójek. W niektórych jeziorach notowano bardzo niską liczbę gatunków od 12 do 29. Do najliczniejszych gatunków należały: Hydrodroma despiciens, Limnesia maculata, Brachypoda versicolor. Do stosunkowo często łowionych zaliczono Limnesia undulata, Piona conglobata, Hygrobates longipalpis, Unionicola minor i Arrenurus albator. Wśród zebranych Hydrachnidia wyróżniono 6 elementów faunistycznych: jeziorny, eurytopowy drobnozbiornikowy, tyrfofilny, reobiontyczny i reofilny oraz gatunki astatycznej fauny wiosennej. W strukturze gatunkowej przeważa element jeziorny, a w strukturze liczebności eurytopowy drobnozbiornikowy.

Badane jeziora charakteryzują się dość niskim podobieństwem fauny. Najbardziej zbliżone faunistycznie sa jeziora o charakterze dystroficznym: Klimunt i Skarp, a jezioro Majcz Wielki najbardziej odbiega faunistycznie od pozostałych jezior. Tylko $w$ jednym $\mathrm{z}$ badanych jezior (Mokre) odnotowano gatunek wskaźnikowy mezotrofii - Atractides lacustris. We wszystkich 
występowały gatunki wskaźnikowe umiarkowanej eutrofii. Wśród nich można wyróżnić: Limnesia polonica, Atractides ovalis, Unionicola minor, Piona stjoerdalensis, P. rotundoides, Forelia spatulifera. Do jezior o najlepszej kondycji ekologicznej można zaliczyć: Majcz Wielki, Mokre, Duś.

W Jeziorze Mokrym przeprowadzono analize pionowego i siedliskowego rozmieszczenia gatunków. W miarę zwiększania się głębokości liczba osobników i różnorodność gatunkowa malała. Najwięcej wodopójek łowiono w strefie głębokości do $0,5 \mathrm{~m}$. W strefie głębokości 2-3 m wyraźnie wzrasta zróżnicowanie gatunkowe. Większość gatunków reprezentowała element jeziorny. Na głębokości 4 i 5 m zaobserwowano znacznie mniej wodopójek, a na głębokości 6 m odnotowano tylko 2 osobniki należące do dwóch gatunków. Poniżej $6 \mathrm{~m}$ nie notowano już wodopójek. Najwięcej gatunków odnotowano w siedliskach fitolitoralu porośniętym Phragmites australis i Schoenoplectus lacustris, zaś najwięcej osobników zebrano w siedliskach dna piaszczystego nieporośniętego.

Jeziora Mazurskiego Parku Krajobrazowego, na tle innych jezior Polski, charakteryzują się małym zróżnicowaniem gatunkowym, niską liczbą gatunków wskaźnikowych mezotrofii i dość wysoką liczbą gatunków wskaźnikowych, świadczących o umiarkowanej eutrofii. 